\title{
PENGARUH KOMPETENSI DIMODERASI OLEH TEKNOLOGI INFORMASI KOMUNIKASI TERHADAP KINERJA PELAYANAN PUBLIK
}

\author{
Maulana Ali \\ Ilmu Pemerintahan, Pascasarjana , Universitas Tamansiswa Palembang \\ Jalan Tamansiswa No. 261, Palembang, 30126 \\ E-mail : maulana@unitaspalembang.ac.id
}

\begin{abstract}
ABSTRAK
Pelayanan publik menjadi fokus pembicaraan di era keterbukaan saat ini, khususnya dalam memasuki era revolusi industri 4.0. Penelitian ini bertujuan ingin melihat pengaruh kompetensi dengan dimoderasi oleh penguasaan Teknologi Informasi dan Komunikasi terhadap kinerja pelayanan pada kantor pelayanan publik di Kota Palembang. Penelitian ini dilakukan dengan metode purposive sampling dengan sampel sebanyak 100 lembaga usaha yang menerima pelayanan dari kantor pelayanan publik di kota Palembang. Pengumpulan data primer dilakukan dengan kuesioner yang berisi tanggapan dari responden. Data yang terkumpul selanjutnya dianalisis dengan menggunakan program SPSS (Statistical Product and Service Solution) versi 20. Setelah dilakukan uji validitas dan reliabilitas; selanjutnya dilakukan uji kelayakan model berdasarkan nilai Goodness of Fit (GoF); Uji Hipotesis untuk menguji pengaruh kompetensi dengan moderasi penguasaan Teknologi Informasi dan Komunikasi terhadap kinerja pelayanan kantor publik di Kota Palembang dilakukan dengan menggunakan Teknik analisis Structural Equation Model (SEM) dengan menggunakan software AMOS 20.0.. Hasil dari pengujian ini menunjukkan aspek kompetensi berpengaruh secara positif dan signifikan sebesar 0,81 terhadap kinerja pelayanan dan semakin menguat pengaruhnya jika dimoderasi oleh penguasaan Teknologi Informasi dan Komunikasi menjadi sebesar 0,91 .
\end{abstract}

Kata Kunci: Kinerja Pelayanan, Kompetensi, Teknologi Informasi dan Komunikasi

\section{PENDAHULUAN}

Memasuki Era Revolusi Industri 4.0 organisasi dituntut untuk mengalokasikan anggaran yang cukup besar pada investasi dalam teknologi informasi, hal ini dipandang perlu sebagai upaya untuk mengambil keuntungan pada persaingan secara global. Investasi pada teknologi informasi dewasa ini menjadi fokus utama para manajer berdasarkan imbalan keuntungan yang akan diperoleh. Pemanfaatan teknologi informasi dapat dilakukan secara efektif jika anggota dalam organisasi dapat menggunakan teknologi tersebut dengan baik. Pemanfaatan teknologi secara efektif akan meningkatkan kinerja. (Muzakki, Susilo, Yuniarto, 2016), hal ini sesuai dengan model penerimaan teknologi (technology acceptance model/TAM). TAM (Technology Acceptance Model) menyatakan bahwa pemanfaatan teknologi informasi dapat meningkatkan kinerja. Kinerja itu sendiri berkaitan dengan pencapaian prestasi kerja individu di dalam organisasi yang merupakan hasil upaya seseorang yang ditentukan oleh kemampuan karakteristik pribadi serta persepsi terhadap perannya pada pekerjaan itu (Sutrisno, 2011:149)

Susanto (2013) menyatakan bahwa sekelompok perangkat keras dan perangkat lunak atau yang disebut sistem informasi berbasis komputer yang digunakan untuk memproses data menjadi sebuah informasi yang bisa memberikan manfaat. Penggunaan perangkat keras dan perangkat lunak tersebut dimaksudkan untuk menghasilkan informasi secara cepat dan akurat. Sejalan dengan penelitian yang dilakukan Eria, Zulbahridar Ilham, (2014) menyatakan bahwa teknologi informasi memiliki pengaruh terhadap kinerja perusahaan sehingga bisa disimpulkan bahwa Informasi teknologi sangat berperan untuk meningkatkan kualitas pelayanan di sektor publik.

Perkembangan teknologi informasi dan komunikasi memudahkan masyarakat untuk mengakses informasi di seluruh dunia. Sebagai bagian yang bersifat dinamis Masyarakat senantiasa mengalami dinamika perubahan baik dilihat secara fisik dalam arti perubahan yang menyangkut jenis, jumlah, dan mutu fasilitas material berkaitan dengan interaksi sosial maupun non fisik. Perubahan juga terjadi karena dipengaruhi beberapa faktor antara lain komunikasi, cara dan pola pikir masyarakat. (Nasution, 2017). (Luftman, Jerry \& Seif dkk., 2012).

Aspek Kemampuan sumber daya manusia organisasi untuk mengoperasikan dan memelihara sistem berfungsi secara optimal dan berkelanjutan juga harus diperhatikan (Hertati, 2015). Kemampuan dan keandalan sistem yang tinggi dalam jangka panjang menjadi kurang berpengaruh ketika kapasitas sumber daya manusia dalam organisasi tidak diperbaiki. Khususnya itu keahlian, kemampuan teknis dan kualitas personel yang baik untuk keahlian pegawai negeri, antara lain: (1) Memiliki pengalaman sesuai dengan tugas dan fungsinya; (2) Minta pegawai negeri yang berkualitas dapat dilihat dari tiga elemen utama, yaitu: pengetahuan 
mendalam di bidangnya; (3) Memiliki wawasan yang jelas; (4) Etis. Untuk kemampuan teknis, di antara pegawai negeri lainnya harus memahami tugas di bidangnya. Adapun kualitas karyawan yang baik antara lain harus memiliki disiplin yang tinggi, jujur, sabar, menaruh minat, terbuka, obyektif, pandai berkomunikasi, selalu siap dan terlatih (Sujadi, 2010).

Pemerintah Kota Palembang dalam upaya meningkatkan kualitas pelayanan kepada masyarakat yang akan mengurus perizinan ataupun non perizinan telah membuka Kantor pelayan publik satu pintu. Kantor pelayanan satu pintu memainkan peran penting dalam pencapaian tujuan pemerintah kota dalam mewujudkan terwujudnya Good Governance dan peran ini menjadi lebih penting dalam adopsi dan integrasi Teknologi Informasi dan Komunikasi (ICT) untuk penyediaan layanan informasi dan pengurusan kepentingan perizinan serta surat menyurat yang dibutuhkan oleh masyarakat. Harapan masyarakat akan kualitas pelayanan yang prima dirasakan belum maksimal.

\section{RUANG LINGKUP}

Dalam penelitian ini permasalahan mencakup:

1. Cakupan permasalahan.

Cakupan permasalahan pada Penelitian ini adalah kinerja pelayanan pada kantor pelayanan publik di Kota Palembang

2. Batasan-batasan penelitian.

Penelitian ini hanya dibatasi pada bahasan mengenai pengaruh kompetensi dengan dimoderasi oleh penguasaan Teknologi Informasi dan Komunikasi terhadap kinerja pelayanan pada kantor pelayanan publik di Kota Palembang.

3. Rencana hasil yang didapatkan.

Rencana hasil yang didapatkan dari Penelitian ini adalah diduga kompetensi berpengaruh secara positif dan signifikan terhadap kinerja pelayanan dan semakin menguat pengaruhnya jika dimoderasi oleh penguasaan Teknologi Informasi dan Komunikasi.

\section{BAHAN DAN METODE}

Pendekatan yang digunakan dalam penelitian ini adalah pendekatan kuantitatif, dengan menggunakan metode survei. Penelitian ini dikembangkan dengan menggunakan pendekatan model matematis, teori serta hipotesis dengan menggunakan kuesioner yang diberikan kepada sampel dari populasi masyarakat dan pengusaha yang melakukan pengurusan surat perizinan dan non perizinan di kantor pelayanan satu pintu kota Palembang.

\subsection{Teknik Pengumpulan dan Sumber Data}

Pengumpulan data dilakukan dengan metode purposive sampling dengan kriteria yang telah ditentukan yaitu responden masyarakat umum dan pengusaha yang melakukan pengurusan surat izin dan non izin pada kantor pelayanan satu pintu kota Palembang dengan jumlah responden sebanyak 150 orang. Pengumpulan data dilakukan dengan metode survei melalui kuesioner dengan lokasi penyebaran di kantor pelayanan satu pintu Kota Palembang dalam kurun waktu 3 bulan.

\subsection{Metode Analisis Data}

Data primer dikumpulkan dari hasil penyebaran kuesioner yang berisi daftar pertanyaan dari masingmasing variabel yang meliputi;

Menurut Spencer (dalam Moeheriono, 2012), Variabel Kompetensi adalah sebagai karakteristik yang mendasari seseorang dan berkaitan dengan efektifitas kinerja individu dalam pekerjaannya (an underlying characteristic's of an individual which is causally related to criterion - referenced effective and or superior performance in a job or situation). Underlying Characteristics mengandung makna kompetensi adalah bagian dari kepribadian yang mendalam dan melekat kepada seseorang serta perilaku yang dapat diprediksi pada berbagai keadaan dan tugas pekerjaan. Terdapat 4 indikator yang meliputi pengalaman, ketrampilan, sikap dan tanggung jawab.

Variabel Teknologi Informasi adalah "Teknologi informasi adalah suatu teknologi yang digunakan untuk mengolah data, termasuk memproses, mendapatkan, menyusun, menyimpan, memanipulasi data dalam berbagai cara untuk menghasilkan informasi yang berkualitas, yaitu informasi yang relevan, akurat dan tepat waktu, yang digunakan keperluan pribadi, bisnis, dan pemerintahan dan merupakan informasi yang strategis untuk pengambilan keputusan". (Sutabri, 2014)

Variabel Kualitas pelayanan publik adalah tingkat karakteristik yang melekat pada kualitas pelayanan yang diberikan kepada pelanggan sesuai dengan standar pelayanan yang telah dibakukan sebagai pedoman dalam memberikan layanan. Standar pelayanan adalah ukuran yang telah ditentukan sebagai suatu pembakuan pelayanan yang baik. Indikator adalah tolak ukur dari kinerja pelayanan publik, dalam pelayanan publik terdapat lima dimensi, yaitu: Dimensi tangible, Dimensi reliability, Dimensi responsiveness, Dimensi assurance, Dimensi emphaty. (Psychologymania, 2012).

Data sekunder dikumpulkan dalam 4 langkah yaitu editing, entry, tabulasi, kemudian data dianalisis dengan menggunakan SPSS versi 20 dan Amos versi 20. Adapun desain penelitian yang digunakan adalah desain penelitian kausalitas (sebab dan akibat). Alat uji statistik digunakan dalam penelitian ini untuk menguji hipotesis. Sebelum menguji data, validitas dan reliabilitas diuji. Selanjutnya, analisis statistik diferensial dilakukan dengan menggunakan analisis jalur.

\section{PEMBAHASAN}

Dalam penelitian dilakukan beberapa tahap uji antara lain uji validitas dan reliabilitas dengan menggunakan software SPSS versi 20. Selanjutnya dilakukan uji model dengan menggunakan Amos versi 20. 


\subsection{Uji Validitas dan Uji Reliabilitas}

Uji validitas dilakukan dengan menghitung koefisien korelasi (r) antara skor item pengukuran dengan skor totalnya. Seluruh butir pertanyaan dinyatakan valid dengan nilai lebih dari 0,201. Pengujian reliabilitas diperoleh dari nilai koefisien reliabilitas total Cronbach's Alpha dan hasil pengujian memperoleh nilai masingmasing variabel di atas 0,60. Dengan demikian, seluruh indikator terbukti reliabel dalam mengukur variabel latennya masing-masing.

\subsection{Model Struktural}

Model struktural pada penelitian ini yang disajikan pada gambar 1, menggabungkan model variabel eksogen dan variabel endogen. Model persamaan struktural yang dihasilkan dalam penelitian ini, secara formulasi dapat dituliskan sebagai berikut :

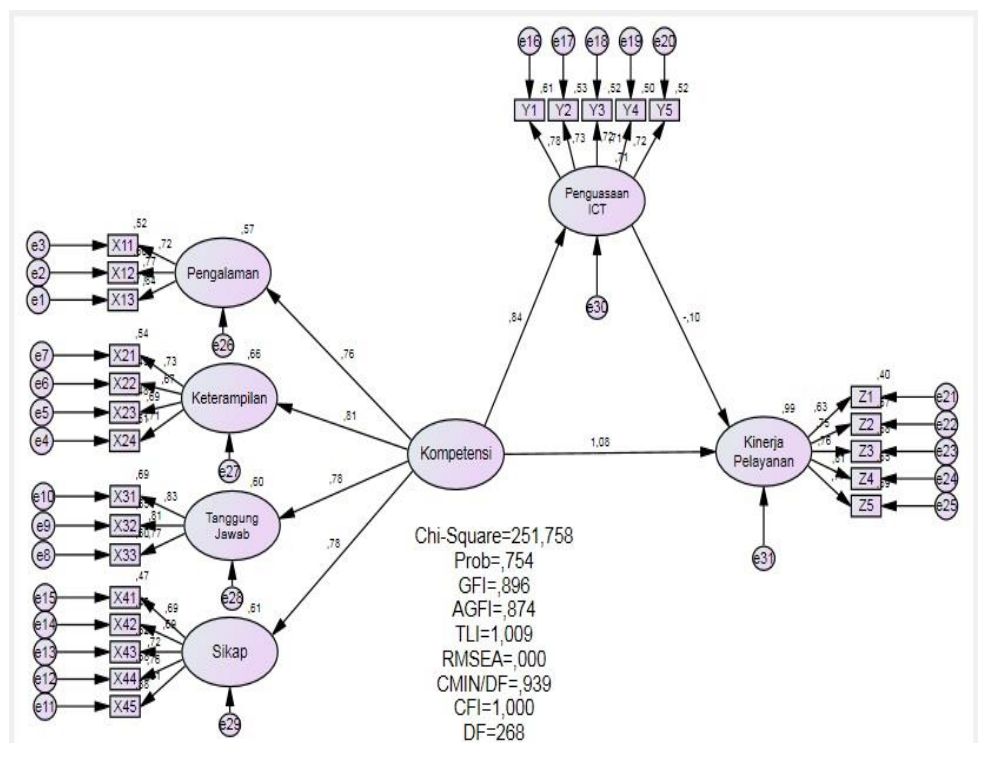

Gambar 1. Full Standardized Model Persamaan Struktural

Path Analysis (1).

$\mathrm{Y} 1=\rho \mathrm{x} 1 \mathrm{y} 1 . \mathrm{X} 1+\rho \mathrm{x} 2 \mathrm{y} 1 . \mathrm{X} 2+\rho \mathrm{x} 3 \mathrm{y} 1 . \mathrm{X} 3+$ $\rho \mathrm{x} 4 \mathrm{y} 1 . \mathrm{X} 4+\varepsilon$

Y1 $=0,141 \mathrm{X} 1+0,188 \mathrm{X} 2+0,220 \mathrm{X} 3+0,261 \mathrm{X} 4$

Path Analysis (2).

$\mathrm{Y} 2=\rho \mathrm{x} 1 \mathrm{y} 2 . \mathrm{X} 1+\rho \mathrm{x} 2 \mathrm{y} 2 . \mathrm{X} 2+\rho \mathrm{x} 3 \mathrm{y} 3 . \mathrm{X} 3+$ $\rho \mathrm{x} 4 \mathrm{y} 1 . \mathrm{X} 4+\rho \mathrm{y} 1 \mathrm{y} 2 . \mathrm{Y} 1+\varepsilon$

$\mathrm{Y} 2=0,129 \mathrm{X} 1+0,171 \mathrm{X} 2+0,201 \mathrm{X} 3+0,237 \mathrm{X} 4+$ $0,910 \mathrm{Y} 1$

\subsection{Confirmatory Factor Analysis}

Nilai factor loading yang diprasyaratkan harus memenuhi kriteria $\geq 0,50$ (Ghozali, 2013). Berdasarkan hasil pengolahan data menunjukkan bahwa masingmasing indikator pada variabel pengalaman, ketrampilan, tanggung jawab dan sikap memiliki nilai loading factor loading $>0,50$. Oleh karna itu dapat disimpulkan seluruh indikator mampu membentuk variabel latennya (pengalaman, ketrampilan, tanggung jawab dan sikap).

\subsection{Penilaian Kesesuaian Model (Goodness of Fit Index)}

Hasil pengujian terhadap goodness of fit index pada tabel 1 model struktural yang dihasilkan dalam penelitian memiliki kesesuaian yang memenuhi kriteria Goodness of Fit Index yang baik terkecuali untuk nilai GFI dan AGFI yang nilainya masih belum memenuhi kriteria yang ditetapkan atau dengan kata lain nilai tersebut dapat dikatakan marginal dan model yang diajukan dapat diterima.

Tabel 1. Penilaian Kesesuaian Model (Goodness of Fit Index)

\begin{tabular}{|c|c|c|c|}
\hline $\begin{array}{c}\text { Goodness of } \\
\text { Fit }\end{array}$ & $\begin{array}{c}\text { Cut off } \\
\text { value }\end{array}$ & Hasil & Keputusan \\
\hline $\begin{array}{c}\text { Probabilitas } \\
\text { Chi Square }\end{array}$ & $\geq 0,05$ & 0,754 & Good Fit \\
\hline CMIN/DF & $\leq 2,00$ & 0,939 & Good Fit \\
\hline GFI & $\geq 0,90$ & 0,896 & Marginal Fit \\
\hline AGFI & $\geq 0,90$ & 0,874 & Marginal Fit \\
\hline CFI & $\geq 0,90$ & 1,000 & Good Fit \\
\hline TLI & $\geq 0,90$ & 1,009 & Good Fit \\
\hline IFI & $\geq 0,90$ & 1,008 & Good Fit \\
\hline RMSEA & $\leq 0,08$ & 0,000 & Good Fit \\
\hline
\end{tabular}


Tabel 2. Regression Weights: (Group number 1 Default model)

\begin{tabular}{|c|c|c|c|c|c|c|c|}
\hline Penguasaan_ICT & $<-$ & Pengalaman & $\begin{array}{c}\text { Estimate } \\
, 220\end{array}$ & $\begin{array}{l}\text { S.E. } \\
, 071\end{array}$ & $\begin{array}{l}\text { C.R. } \\
3,097\end{array}$ & $\begin{array}{c}\mathrm{P} \\
, 002\end{array}$ & $\begin{array}{r}\text { Label } \\
\text { par_20 }\end{array}$ \\
\hline Penguasaan_ICT & $<-$ & Keterampilan & , 188 &, 069 & 2,727 & ,006 & par_21 \\
\hline Penguasaan_ICT & $<-$ & Tanggung_Jawab & , 141 &, 052 & 2,714 & ,007 & par_22 \\
\hline Penguasaan_ICT & $<-$ & Sikap & ,261 & ,095 & 2,741 & ,006 & par_23 \\
\hline Kinerja_Pelayanan & $<-$ & Penguasaan_ICT & ,910 &, 117 & 7,790 & $* * *$ & par_24 \\
\hline $\mathrm{X} 13$ & $<-$ & Pengalaman & 1,000 & & & & \\
\hline $\mathrm{X} 12$ & $<--$ & Pengalaman & ,930 & ,089 & 10,454 & $* * *$ & par_1 \\
\hline $\mathrm{X} 11$ & $<-$ & Pengalaman & 1,199 & ,128 & 9,374 & $* * *$ & par_2 \\
\hline $\mathrm{X} 24$ & $<-$ & Keterampilan & 1,000 & & & & \\
\hline $\mathrm{X} 23$ & $<--$ & Keterampilan & 1,005 &, 123 & 8,173 & $* * *$ & par_3 \\
\hline $\mathrm{X} 22$ & $<--$ & Keterampilan &, 583 &, 083 & 7,041 & $* * *$ & par_4 \\
\hline $\mathrm{X} 21$ & $<-$ & Keterampilan & ,628 & ,084 & 7,500 & $* * *$ & par_5 \\
\hline $\mathrm{X} 33$ & $<-$ & Tanggung_Jawab & 1,000 & & & & \\
\hline $\mathrm{X} 32$ & $<--$ & Tanggung_Jawab & 1,059 & ,105 & 10,064 & $* * *$ & par_6 \\
\hline $\mathrm{X} 31$ & $<-$ & Tanggung_Jawab & ,654 &, 064 & 10,190 & $* * *$ & par_7 \\
\hline $\mathrm{X} 45$ & $<--$ & Sikap & 1,000 & & & & \\
\hline $\mathrm{X} 44$ & $<--$ & Sikap & 1,109 & ,149 & 7,438 & *** & par_8 \\
\hline $\mathrm{X} 43$ & $<-$ & Sikap & 1,117 &, 155 & 7,208 & $* * *$ & par_9 \\
\hline $\mathrm{X} 42$ & $<--$ & Sikap & 1,013 & ,143 & 7,092 & *** & par_10 \\
\hline $\mathrm{X} 41$ & $<-$ & Sikap & ,901 & ,130 & 6,943 & *** & par_11 \\
\hline Y1 & $<-$ & Penguasaan_ICT & 1,000 & & & & \\
\hline Y2 & $<--$ & Penguasaan_ICT & 891 & ,098 & 9,059 & $* * *$ & par_12 \\
\hline Y3 & $<--$ & Penguasaan_ICT & ,873 &, 102 & 8,533 & $* * *$ & par_13 \\
\hline Y4 & $<--$ & Penguasaan_ICT & 917 &, 106 & 8,619 & $* * *$ & par_14 \\
\hline Y5 & $<-$ & Penguasaan_ICT & ,911 &, 102 & 8,934 & $* * *$ & par_15 \\
\hline $\mathrm{Z} 1$ & $<-$ & Kierja_Pelayanan & 1,000 & & & & \\
\hline $\mathrm{Z} 2$ & $<--$ & Kinerja_Pelayanan & ,942 &, 115 & 8,214 & $* * *$ & par_16 \\
\hline $\mathrm{Z} 3$ & $<--$ & Kinerja_Pelayanan & 1,041 & ,124 & 8,400 & $* * *$ & par_17 \\
\hline $\mathrm{Z} 4$ & $<--$ & Kinerja_Pelayanan & 1,111 & ,127 & 8,717 & $* * *$ & par_18 \\
\hline $\mathrm{Z5}$ & $<-$ & Kinerja_Pelayanan & 1,111 &, 132 & 8,391 & $* * *$ & par_19 \\
\hline
\end{tabular}

Berdasarkan hasil olahan data pada tabel 2, dapat ditarik kesimpulan sebagai berikut:

1. Pengalaman berpengaruh signifikan terhadap Penguasaan ICT, karena nilai P Value $(0,002)<0.05$.

2. Keterampilan berpengaruh signifikan terhadap Penguasaan ICT, karena nilai P Value $(0,006)<0.05$.

3. Tanggung Jawab berpengaruh signifikan terhadap Penguasaan ICT, karena nilai P Value $(0,007)<0.05$.

4. Sikap berpengaruh signifikan terhadap Penguasaan ICT, karena nilai P Value $(0,006)<0.05$.

5. Penguasaan ICT berpengaruh signifikan terhadap Kinerja Pelayanan, karena nilai $\mathrm{P}$ Value $(* * *)<0.0$

Tabel 3. Indirect Effects (Group number 1 - Direct Model)

Indirect Effects (Group number 1 - Direct Model)

\begin{tabular}{lrrrr} 
& Sikap & Tanggung Jawab & Keterampilan & Pengalaman \\
\hline Penguasaan ICT & 0 & 0 & 0 & 0 \\
\hline Kinerja Pelayanan & 0,129 & 0,171 & 0,201 & 0,237 \\
\hline & & & & \\
\hline & $\mathbf{2} \%$ & $\mathbf{3} \%$ & $\mathbf{4} \%$ & $\mathbf{6 \%}$
\end{tabular}

Berdasarkan tabel 3 di atas, diperoleh hasil sebagai berikut:

1. Pengaruh tidak langsung Sikap terhadap Kinerja Pelayanan sebesar $2 \%$.

2. Pengaruh tidak langsung Tanggung Jawab terhadap Kinerja Pelayanan sebesar 3\%.

3. Pengaruh Keterampilan terhadap Kinerja Pelayanan sebesar $4 \%$.

4. Pengaruh Pengalaman terhadap Kinerja Pelayanan sebesar $6 \%$.

Untuk melihat pengaruh langsung Penguasaan ICT terhadap Kinerja Pelayanan, dapat dilihat pada tabel 4.
Tabel 4. Standardized Direct Effects (Group number 1 - Default model)

Standardized Direct Effects (Group number 1 - Direct Model)

\begin{tabular}{|l|r|r|r|r|r|}
\hline & Sikap & $\begin{array}{r}\text { Tanggung } \\
\text { Jawab }\end{array}$ & Keterampilan & Pengalaman & \multicolumn{2}{|l|}{$\begin{array}{l}\text { Penguasaan } \\
\text { ICT }\end{array}$} \\
\hline Penguasaan ICT & 0,246 & 0,277 & 0,272 & 0,267 & 0 \\
\hline Kinerja Pelayanan & 0 & 0 & 0 & 0 & 0,923 \\
\hline \multicolumn{7}{|c|}{} & & $85 \%$ \\
\hline
\end{tabular}

Dari tabel 4 di atas, diketahui bahwa Pengaruh langsung Penguasaan ICT terhadap Kinerja Pelayanan sebesar $85 \%$. Untuk mengetahui besarnya pengaruh masing-masing indikator terhadap kinerja pelayanan melalui ICT, dapat dilihat pada tabel 5.

Tabel 5. Regression Weights: (Group number 1 Direct Model)

Regression Weights: (Group number 1 - Direct Model)

\begin{tabular}{|l|r|l|r|r|}
\hline & & & Estimate & S.E. \\
\hline Penguasaan ICT & $<-$. & Sikap & 0,22 & 0,071 \\
\hline Penguasaan ICT & $<-$. & Tanggung jawab & 0,188 & 0,069 \\
\hline Penguasaan ICT & $<-$. & Keteramilan & 0,141 & 0,052 \\
\hline & & & & \\
Penguasaan ICT & $<-$. & Pengalaman & 0,261 & 0,095 \\
\hline & & & & \\
Kinerja Pelayanan & $<--$ & Penguasaan ICT & 0,91 & 0,117 \\
\hline
\end{tabular}

Untuk 100 sampel, diperoleh nilai $\mathrm{T}_{\text {tabel }}$ sebesar 1,97. Dengan demikian, variabel dikatakan berpengaruh jika nilainya lebih besar daripada 1,97 ( $\left.\mathrm{T}_{\text {tsbel }}\right)$. Dari analisis yang dilakukan dengan menggunakan (3).

$\mathrm{Sab}=\sqrt{b^{2} S a^{2}+a^{2} S b^{2}+S a^{2} S b^{2}}$

Keterangan (3).

$\mathrm{a}=0,22$

$\mathrm{b}=0,91$

$\mathrm{Sa}=0,071$

$\mathrm{Sb}=0,117$

Tabel 6. Pengaruh Masing-masing Variabel Bebas terhadap Variabel Terikat Melalui Variabel Moderasi

\begin{tabular}{|l|l|l|}
\hline 1 & X1 terhadap Z melalui Y & 9,1 \\
\hline 2 & X2 terhadap Z melalui Y & 3,89 \\
\hline 3 & X3 terhadap Z melalui Y & 2,98 \\
\hline 4 & X4 terhadap Z melalui Y & 29,69 \\
\hline
\end{tabular}


Dengan demikian dapat disimpulkan bahwa:

1. Pengaruh Sikap terhadap Kinerja Pelayanan melalui Penguasaan ICT sebesar 9,1 > 1,97 ( $\left.\mathrm{T}_{\text {tabel }}\right)$, dengan demikian masuk dalam kriteria signifikan.

2. Pengaruh Tanggung jawab terhadap Kinerja Pelayanan melalui Penguasaan ICT sebesar 3,89 > 1,97 $\left(\mathrm{T}_{\text {tabel }}\right)$, dengan demikian masuk dalam kriteria signifikan.

3. Pengaruh Keterampilan terhadap Kinerja Pelayanan melalui Penguasaan ICT sebesar 2,98 > 1,97 ( $\left.\mathrm{T}_{\text {tabel }}\right)$, dengan demikian masuk dalam kriteria signifikan.

4. Pengaruh Pengalaman terhadap Kinerja Pelayanan melalui Penguasaan ICT sebesar 29,69>1,97 ( $\left.\mathrm{T}_{\text {tabel }}\right)$, dengan demikian masuk dalam kriteria signifikan.

Mengacu dari hasil pengolahan data pada penelitian ini terlihat kompetensi baik secara langsung maupun tidak langsung berpengaruh terhadap kualitas pelayanan di Kantor pelayanan satu pintu kota Palembang. Variabel Penguasaan ICT memediasi variabel-variabel independen Sikap (X1), Tanggung jawab (X2), Keterampilan (X3), dan Pengalaman (X4) serta moderasi oleh penguasaan ICT terhadap variabel dependen Kinerja Pelayanan (Y). Hal ini menunjukkan bahwa peningkatan kompetensi sumber daya manusia khususnya aparatur sipil negara dalam konteks penguasaan ICT harus terus ditingkatkan. Baik dari peningkatan kualitas sikap, tanggung jawab, ketrampilan dan pengalaman. hal itu bisa dilakukan dengan terus mengikuti pendidikan dan pelatihan dalam konteks penguasaan soft or hard kompetensinya.

Perusahaan-perusahaan yang menggabungkan TIK dengan perubahan organisasi memiliki yang tinggi insiden peningkatan produktivitas dan memiliki tingkat inovasi yang tinggi. Hasil kami juga menunjukkan bahwa ICT dan modal manusia adalah pelengkap dalam dinas layanan dan distribusi dinamis. Perusahaanperusahaan yang menggunakan penggabungan antara kompetensi sumber daya manusia dan ICT akan meningkatkan produktivitas yang lebih tinggi termasuk peningkatan inovasinya. Hasil penelitian ini sejalan dengan penelitian yang dilakukan oleh Bucur, 2013; Oguce, 2017; Fahlefi, 2014. Hasil studi ini juga menunjukkan bahwa investasi ICT, disertai dengan perubahan organisasi dan investasi dalam sumber daya manusia, memiliki dampak yang signifikan terhadap produktivitas dan kinerja ekonomi termasuk pelayanan. Dengan kata lain, perusahaan yang sukses mengadopsi ICT sebagai bagian dari sistem atau sekelompok organisasi yang saling memperkuat perubahan.

Oleh karena itu, hasil penelitian ini merekomendasikan antara lain bahwa pendidikan dan pelatihan yang berkesinambungan dalam hal penguasaan ICT harus terus dilakukan untuk meningkatkan kualitas pelayanan. (Daniella, 2010). ini sesuai dengan amanah bahwa membangun kepercayaan masyarakat atas pelayanan publik yang dilakukan penyelenggara pelayanan publik merupakan kegiatan yang harus dilakukan seiring dengan harapan dan tuntutan seluruh warga negara dan penduduk tentang peningkatan pelayanan publik. (Undang-Undang No 25 Tahun 2009 tentang Kebijakan Publik).

\section{KESIMPULAN}

Hasil penelitian ini menunjukkan bahwa kompetensi dimoderasi oleh penguasaan ICT mampu meningkatkan kinerja pelayanan publik pada kantor pelayanan satu pintu di kota Palembang. Variabel Penguasaan ICT memediasi variabel-variabel independen Sikap (X1), Tanggung jawab (X2), Keterampilan (X3), dan Pengalaman (X4) serta moderasi oleh penguasaan ICT terhadap variabel dependen Kinerja Pelayanan (Y). Hal ini menunjukkan bahwa peningkatan kompetensi sumber daya manusia khususnya aparatur sipil negara dalam konteks penguasaan ICT harus terus ditingkatkan. Baik dari peningkatan kualitas sikap, tanggung jawab, ketrampilan dan pengalaman. hal itu bisa dilakukan dengan terus mengikuti pendidikan dan pelatihan dalam konteks penguasaan soft or hard kompetensinya. Instansi-instansi yang terkait dengan pelayanan publik diharapkan terus meningkatkan kualitas pelayanannya sesuai dengan standar ISO.

\section{SARAN}

Berkaitan dengan hasil penelitian ini diharapkan pemerintah kota Palembang untuk terus berusaha meningkatkan kompetensi para pegawai yang berkaitan dengan pelayanan kepada masyarakat melalui kegiatan pendidikan dan pelatihan yang berkesinambungan dalam konteks penguasaan teknologi informasi dan komunikasi.

\section{DAFTAR PUSTAKA}

Susanto, A 2013. Sistem Informasi Akuntansi Edisi Sembilan. Yogyakarta: ANDI.

Bucur, I. 2013. Managerial core competencies as predictors of managerial performance, on Diff erent Levels of Management. Procedia - Social and Behavioural Science, 78: 365-369.

Ghozali, I., 2013. Aplikasi Analisis Multivariate Dengan Program Ibm Spss 21. Edisi 7. Semarang: Badan Penerbit Universitas Diponegoro.

Hertati, L. 2015. Competence of Human Resources, The Benefits of Information Technology on Value of Financial Reporting in Indonesia. Research Journal of Finance and Accounting. Vol.6, No.8.

Luftman, J., Zadeh, H. S., Derksen, B., Santana, M., Rigoni, E. H., \& Huang, Z. 2012. Key information technology and management issues 2011-2012: An international study. Journal of Information Technology. 28. 198-212. 10.1057/jit.2013.22.

Moeheriono. 2012. Pengukuran Kinerja Berbasis Kompetensi, Cetakan kedua, Jakarta: Ghalia Indonesia. 
Muzakki, M. H., Susilo, H., \& Yuniarto, S. R. 2016. Pengaruh Penggunaan Teknologi Informasi Terhadap Kinerja Karyawan (Studi Pada Karyawan PT. TELKOM Pusat Divisi Regional V Surabaya). Jurnal Administrasi Bisnis (JAB) Vol. 39 No.2 Oktober

Nasution, R, J. 2017. Pengaruh Perkembangan Teknologi Informasi Komunikasi Terhadap Eksistensi Budaya Lokal. Jurnal Penelitian Komunikasi dan Opini Publik Vol. 21 No. 1, : 30-42 Juni 2017.

Oguce, D (2017). Impact of Information and Communication Technology (ICT) Literacy competence on Job Performance of Librarians in Federal University Libraries in Nigeria. The Information Technologist Vol 13. No.1 June.

Psychologymania. 2012. "pengertian kualitas pelayanan publik"dalam http://www.psychologymania.com/20 12/12/pengertian-kualitas-pelayanan-publik.html ( 21/11/13)

Ryding, D. 2010. The impact of new technologies on customer satisfaction and business to business customer relationships: Evidence from the soft drinks industry. Journal of Retailing and Consumer Services.

17.

224-228.
Sujadi, P.S. 2010. Definisi Kinerja. Jakarta: Rajawali Pers.

Eria, S. Dkk. 2014. Pengaruh Information Technology Relatedness Terhadap Kinerja Perusahaan Dengan Knowledge Management Capability Sebagai Variabel Intervening (Penelitian Terhadap Perusahaan Perbankan Di Kota Pekanbaru) JOM FEKON Vol. 1 No.2 Oktober

Sutrisno, E. 2011. Manajemen Sumber Daya Manusia. Jakarta : Penerbit Kencana

Sutabri, T. 2014. Pengantar Teknologi Informasi. Yogyakarta: Andi

Fahlefi, Z. 2014. Penerapan Teknologi Informasi Bagi Pelaksanaan Pelayanan Publik (Studi Kasus Pada BP2TSP Kota Samarinda) Jurnal Paradigma, Vol.3 No.2, Agustus 2014. ISSN: 2252-4266

Undang-Undang No 25 Tahun 2009 tentang Kebijakan Publik.

\section{UCAPAN TERIMA KASIH}

Terima kasih saya sampaikan kepada Direktur Pascasarjana Universitas Tamansiswa Palembang atas dukungannya terhadap proses penelitian ini hingga menjadi naskah publikasi untuk diterbitkan. 